\title{
Procedure for determining the effect of internal and external factors on the startup thrust spread of a liquid-propellant rocket engine
}

\author{
Institute of Technical Mechanics \\ of the National Academy of Sciences of U kraine and the State Space Agency of U kraine \\ 15 Leshko-Popel St., Dnipro 49005, Ukraine; e-mail: dolmrut@ gmail.com
}

\begin{abstract}
Despite of the package of measures to adjust a liquid-propellant rocket engine (LPRE) to a specified operating regime, minimum acceptable spreads in the geometrical parameters and operating conditions of its units and assemblies steel remain. These internal factors together with external ones (the pressure and temperature of the propellant components at the engine inlet) govern the engine thrust spread. To provide an acceptable engine thrust spread according to the engine requirements specification, it is important to know the spread value as early as at the stage of off-engine tryout of the engine units and assemblies. The aim of this work is to develop a procedure for calculating the effect of external and internal factors on the LPRE startup thrust spread.

This paper presents a procedure for determining the effect of internal and external factors on the LPRE startup thrust spread. The procedure includes the development of a mathematical model of engine startup that accounts for the maximum number of internal factors, the choice of internal factors that produce the maximum effect on the LPRE startup thrust spread, the choice of a method for specifying the external and internal factor spread, engine startup calculations at different combinations of external and internal factor spread values, engine thrust spread determination, determining the statistical and the theoretical distributions of the 90 percent thrust time spread and the steady thrust spread, and assessing their goodness of fit using Pearson's chi-squared test.

The paper gives an example of calculating the effect of the external and internal factor spread on the LPRE startup thrust spread for a staged-combustion oxidizer-rich sustainer LPRE. Using the results of previous calculations, 12 internal factors that produce the maximum effect on the engine startup thrust spread are identified. It is shown that the calculated spread of the 90 percent thrust (combustion chamber pressure) time lies in the range $-0.0822 \mathrm{~s}$ to $+0.0730 \mathrm{~s}$ about its nominal value, and the calculated steady engine thrust (combustion chamber pressure) spread lies in the range -6.4 percent to +6.6 percent of the nominal thrust. Using Pearson's chi-squared test, an estimate is obtained for the goodness of fit of the anticipated theoretical distributions of the 90 percent thrust time spread and the steady thrust spread to the obtained statistical ones.
\end{abstract}

Keywords liquid-propellant rocket engine, startup, mathematical simulation, 90 percent thrust time, external and internal factors, thrust spread, goodness of fit of a theoretical distribution to a statistical one.

1. Gahun G. G., Baulin V. I., Volodin V. A., Kuropatenkov V. D., Kraev M. V., Trofimov V. F. Design of Liquid-Propellant Rocket Engines. Moscow: Mashinostroyeniye, 1989. 424 pp. (in Russian)

2. Makhin V. A., Prisnyakov V. F., Belik N. P. Dynamics of Liquid-Propellant Rocket Engines. Moscow: Mashinostroyeniye, 1969. 834 pp. (in Russian).

3. Shevyakov A. A., Kalnin V. M., Naumenkova M. V., Dyatlov V. G. Theory of Rocket Engine Automatic Control. Moscow: Mashinostroyeniye, 1978. 288 pp. (in Russian).

4. Belyaev E. N., Chervyakov V. V. Mathematical Simulation of liquidPropellant Rocket Engines. Moscow: MAI-PRINT, 2009. 280 pp. (in Russian).

5. Lebedinsky E. V., Zaitsev B. V., Sobolev A. A. Multilevel mathematical simulation of an LPRE flow regulator. Keldysh Research Center website. 2011. P. 10. URL: http://www.Ipre.de/resources/articles/reg_model.pdf (last accessed on October 5, 2021). (in Russian).

6. Pilipenko V. V., Zadontsev V. A., Natanzon M. S. Cavitation Oscillations and Hydrosystem Dynamics. Moscow: Mashinostroyeniye, 1977. 352 pp. (in Russian). 
7. Pylypenko O. V., Prokopchuk A. A., Dolgopolov S. I., Pisarenko V. Yu., Kovalenko V. N., Nikolaev A. D., Khoryak N. V. Peculiarities of mathematical modeling of low-frequency dynamics of the staged liquid rocket sustainer engines at its startup. Space Sci. \& Technol. V. 23. No. 5. Pp. 3-12. (in Russian).

https://doi.org/10.15407/knit2017.05.003

8. Liu Wei, Chen Liping, Xie Gang, Ding Ji, Zhang Haiming, Yang Hao. Modeling and simulation of liquid propellant rocket engine transient performance using Modelica. Proc. of the 11th Int. Modelica Conf., 2015, Sept. 21-23, Versailles. France. p. 485-490. URL:

www.ep.liu.se/ecp/118/052/ecp15118485.pdf of July 13, 2017.

9. Di Matteo, Fr., De Rosa, M., Onofri, M. Start-up transient simulation of a liquid rocket engine. AIAA 2011-6032 47th AIAA/ASME/SAE/ASEE Joint Propulsion Conference \& Exhibit (31 July - 03 August 2011), San Diego, California. $15 \mathrm{pp}$.

https://doi.org/10.2514/6.2011-6032

10. Belov G. V. Mathematical simulation of equilibrium states of multicomponent heterogeneous systems. Matematicheskoye Modelirovaniye. 2005. V. 17. No. 2. Pp. 81-91. (in Russian).

11. Degtyarev A. V. Rocket Engineering. Problems and Prospects. Dnipropetrovsk: ART-PRESS, 2014. 420 pp. (in Russian).

12. Pylypenko V. V., Dorosh N. L., Manko I. K. Experimental study of vapor condensation in the injection of an oxygen gas jet into a liquid oxygen flow. Teh. Meh. 1993. No. 2. Pp. 77-80. (in Russian).

13. Dorosh N. L. Simulation of oxygen steam jet condensation in liquid oxygen. Applied Questions of Mathematical Modelling. V. 3. No. 2.2. 2020. Pp. 149-155. (in Ukrainian). https://doi.org/10.32782/KNTU2618-0340/2020.3.2-2.14

14. Pylypenko V. V., Dolgopopov S. I. Experiment-and-calculation determination of the coefficients of the equation of cavity dynamics in inducerequipped centrifugal pumps of different standard sizes. Teh. Meh. 1998. No. 8. Pp. 50-56. (in Russian). https://doi.org/10.1016/S0262-1762(99)80457-X

15. Pylypenko O. V., Dolhopolov S. I., Nikolayev O. D., Khoriak N. V. Mathematical simulation of the start of a multiengine liquid-propellant rocket propulsion system. Teh. Meh. 2020. No. 1. Pp. 5-19. (in Russian). https://doi.org/10.15407/itm2020.01.005

16. Dolgopolov S. I., Zavoloka A. N., Nikoilaev A. D., Sviridenko N. F., Smolensky D. E. Parametric determination of hydrodynamic processes in feed 
system of space stage in stopping and starting the cruise engine. Teh. Meh. 2015. No. 2. Pp. 23-36. (in Russian),

17. Dolgopolov S. I., Nikolaev A. D. Mathematical modelling low-frequency dynamics of flow controller at various amplitudes of harmonic disturbance. Teh. Meh. 2017. No. 1. Pp. 15-25. (in Russian). https://doi.org/10.15407/itm2017.01.015

18. Germanova E. A., Kolbasenkov A. I., Koshelev I. M., Lavochkin P. S., Martirosov D. S. Ways to damp low-frequency oscillations in a deeply throttled LPRE. Trudy NPO Energomash Imeni Akademika V.P. Glushko 2013. No. 30. Pp. 104-110. (in Russian).

19. Khoriak N. V., Nikolaev A. D. Decomposition and stability analysis of the dynamic system of feed pipelines and an oxidizer-rich staged-combustion sustainer LPRE. Teh. Meh. 2007. No. 1.Pp. 28-42. (in Russian)

20. Pylypenko O. V., Prokopchuk A. A., Dolgopolov S. I., Khoryak N. V., Nikolaev A. D., Pisarenko V. Yu.. Kovalenko V. N. Mathematical simulation and stability analysis of low-frequency processes in a sustainer liquidpropellant rocket engine with generator gas afterburning. Vestnik Dvigatelestroyeniya. 2017. No. 2. Pp. 34-42. (in Russian).

21. Khoriak N. V., Dolhopolov S. I. Features of mathematical simulation of gas path dynamics in the problem of the stability of low-frequency processes in liquid-propellant rocket engines. Teh. Meh. 2017. No. 3. Pp. 30-44. (in Russian). https://doi.org/10.15407/itm2017.03.030

22. Pylypenko O. V., Khoriak N. V., Dolhopolov S. I., Nikolayev O. D. Mathematical simulation of dynamic processes in hydraulic and gas paths at the start of a liquid-propellant rocket engine with generator gas after-burning. Teh. Meh. 2019. No. 4. Pp. 5-20. (in Russian). https://doi.org/10.15407/itm2019.04.005

23. Casiano M. J., Hulka J. R., Yang V. Liquid-propellant rocket engine throttling: A comprehensive review. Journal of Propulsion and Power. 2010. V. 26. No. 5. Pp. 897-923.

https://doi.org/10.2514/1.49791

24. Sobol I. M., Statnikov R. B. Choice of Optimum Parameters in Multicriteria Problems. Moscow: Nauka, 1981. 110 pp. (in Russian).

25. Bendat J., Pearson A. Random Data: Analysis and Measurement Procedures. Moscow: Mir, 1974. 464 pp. (in Russian). 